\title{
Developing an Explanatory Risk Management Model to Comprehend the Employees' Intention to Leave Public Sector Organization
}

\author{
Carolina Prihandinisari ${ }^{1,2}$, Azizur Rahman ${ }^{3, *(\mathbb{D})}$ and John Hicks ${ }^{4}(\mathbb{D}$ \\ 1 Section Head of Withholding Income Taxes at Directorate of Tax Regulations, Directorate General of Tax, \\ Ministry of Finance, Jakarta 12190, Indonesia; carolina.prihandinisari@pajak.go.id \\ 2 School of Management and Marketing, Charles Sturt University, Wagga Wagga, NSW 2678, Australia \\ 3 School of Computing and Mathematics, Charles Sturt University, Wagga Wagga, NSW 2678, Australia \\ 4 School of Accounting and Finance, Charles Sturt University, Bathurst, NSW 2678, Australia; \\ jhicks@csu.edu.au \\ * Correspondence: azrahman@csu.edu.au; Tel.: +61-2-69334744
}

Received: 10 July 2020; Accepted: 1 September 2020; Published: 4 September 2020

\begin{abstract}
This paper reviews research and theory on the important topic of labour turnover resulting from issues related to job performance and/or job satisfaction which have, in turn, been initiated by changes in work motivation. We focus on labour turnover in the public sector-a neglected area of public administration research-and propose an explanatory model of the development of the intention to leave an organization. The model first describes the relationships between work motivation and job performance and/or job satisfaction. It then explains how changes in performance and/or satisfaction result in the formation of an intention to leave public service employment. The paper concludes by identifying key areas for future research.
\end{abstract}

Keywords: financial incentives; public service motivation; job performance; job satisfaction; intention to leave

\section{Introduction}

There is an increasing financial risk management issue arising in many organizations due to a high level of employees' turnover. These organizations are typically suffering from significant costs for employee replacement as well as operational disruptions. There is a growing literature on the topic of employee turnover research (e.g., Tett and Meyer 1993; Griffeth et al. 2000; Podsakoff et al. 2007; Zimmerman and Darnold 2009; Van Iddekinge et al. 2011). Many researchers found that a range of issues are associated with employee overall behavioral aspects that could trigger resignation. This research provides an explicit account of how an employees' intention to leave an organization develops and the important factors that drive to leave the organization.

Over the last several decades, a number of employees' turnover models have been developed by researchers (see, e.g., Bluedorn 1982a; Hellman 1997; Allen and Griffeth 1999; Peterson 2004; Luna-Arocas and Camps 2008; Steel and Lounsbury 2009; Chen et al. 2011). These models range from a theoretical development of employees' turnover puzzles to turnover process modeling. Most of the studies also mainly focused on a typical standpoint of the human resource improvement, especially in the private sector organizations. However, it is significant to analyze an organizational risk management perspective as well, with a focus to the public sector organizations.

Bluedorn (1982a) developed a unified model of turnover which combined three previous models: (i) the casual turnover model (Price 1989), (ii) the intermediate linkages model (Mobley 1977), and (iii) the organizational commitment model (Porter et al. 1974). According to this study, employees' intention 
to quit from an organization is negatively associated with the level of commitment to organization and positively associated with active job searching status. Commitment to the organization is positively linked to both job satisfaction and promotion opportunity, but negatively associated with potential role of conflict, equity, education, or skill development, and routinization, etc. Ultimately, the decision to leave an organization is particularly impacted by some significant factors such as intention to leave, routinization, employee's age, and workplace environment and opportunity (Bluedorn 1982a).

Another model suggests that there have been three distinct routes which led employee to resign from an organization (Allen and Griffeth 1999). First, there was the route associated with a desire to move, as might arise as a result of issues related to job satisfaction, job commitment, or an option to move as appropriate for remuneration contingency. Second, there was the route that arose through the ease of movement as exemplified by the number and quality of alternatives in the job market and moderated by the visibility of those jobs. The final route was in reaction to performance-related shocks associated with, for example, salient performance feedback, or an unsolicited job offer.

In existing literature, most of the studies have primarily concentrated on finding key factors for employee turnover (Ellett et al. 2007; Luna-Arocas and Camps 2008), examining link between employees' work motivation and turnover (Maertz and Griffeth 2004), job performance, and turnover (Allen and Griffeth 1999; Nyberg 2010), public service motivation and turnover (Bright 2008), and employees' sex and turnover (Sousa-Poza and Sousa-Poza 2007; Rutherford et al. 2012). Some other research also compared the worker's turnover between the public sector and private sector organization (e.g., see Carmeli and Weisberg 2006; Wang et al. 2012). Moreover, many scholars have found that there is a significant association between employees' turnover and job satisfaction (Mobley 1977; Hellman 1997; Steel 2002; Chiu and Francesco 2003; Boswell et al. 2005; Carmeli and Weisberg 2006; Spector et al. 2007; Bright 2008; de Moura et al. 2009; Lambert and Hogan 2009; Liu et al. 2010; Chen et al. 2011; Delobelle et al. 2011; Grissom et al. 2012; Wang et al. 2012; Mihajlov and Mihajlov 2016). For example, a recent study in Serbia demonstrates that job satisfaction plays a significant role in the overall courses of turnover, and employees in the public sector have a higher level of extrinsic job satisfaction with a lower level of turnover intentions compared to employees in the private sector (Mihajlov and Mihajlov 2016).

With only a few exceptions, research on turnover has been undertaken exclusively in a business or private sector context as well as from an organizational human resource development perspective. Research on employee turnover in the public sector is still very rare (Meier and Hicklin 2008), especially in a viewpoint of risk management of public sector organizations. To fill this gap in the literature, this review paper proposes an explanatory risk management model to empirically examine the nexus between work motivation and job performance and job satisfaction, and then assesses the impact of job performance and job satisfaction on the intention to leave a public sector organization through the model to minimize effects and potential risk to the organization due to turnover. In this context we have adopted a different perspective in research. The key novelty of this study can be divided into two folds. Firstly, our proposed explanatory model is based on extensive literature review of various behavioral psychology theories from private sector research. As the public sector research, and specially risk management research in public sector is still rare, this paper will fill-in such a research lacuna by focusing on public organizations. Secondly, it adopts a conceptual nature of connecting both theoretical research and public sector organizational research with risk management perception by offering a contemporary organizational risk management model and detailed constituents of it with validation from important literature in one place. This will bring significant benefits to prospective empirical research in the domain of public sector risk management.

The paper is organised as follows. The next section presents an explanatory risk management model of the intention to leave public sector employment. The model is based on a review of the behavioral psychology literature from private sector research. This section also provides an account of various fundamental arguments around the concepts of work motivation. Section 3 considers the literature related to the establishment of relationships between work motivation, job satisfaction and job performance. Section 4 provides an assessment of significant determinants of intention to leave the 
organization with a particular focus on the public sector context. Finally, Section 5 provides a summary of the findings and suggests directions for future research.

\section{An Explanatory Risk Management Model}

Extensive research has linked job satisfaction to turnover intentions. Other variables, such as gender, work motivation, organizational factors, and job performance, have been considered in the literature as moderating or mediating factors. Our model describes the relationships between work motivation and each of job performance and job satisfaction. It also examines how employees' intention to leave public sector organizations can be influenced by their job performance and job satisfaction. Additionally, this research considers the work motivation which comprises the concepts of intrinsic and extrinsic work motivation as well as the public service work motivation. Based on these traditional and contemporary concepts in this research area, we propose an explanatory risk management model of the development of the intention to leave an organization which is illustrated in Figure 1.

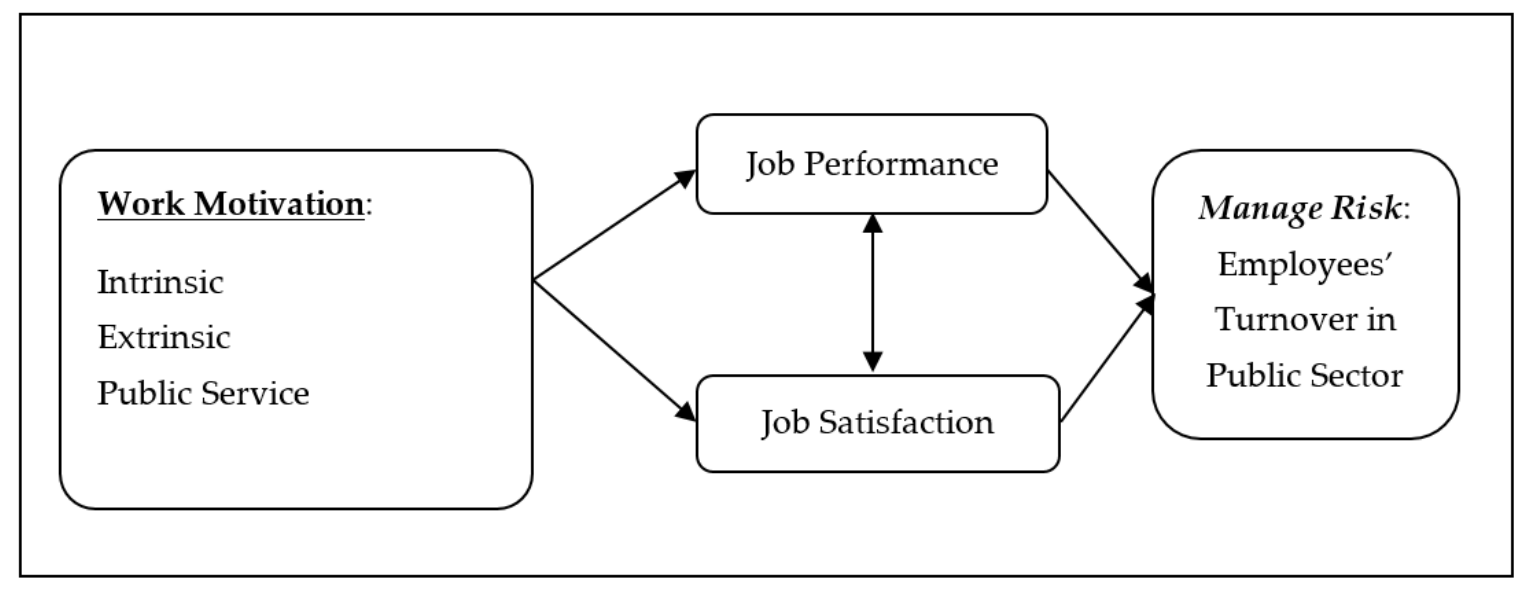

Figure 1. An explanatory risk management model depicting pathways of employee turnover in the public sector.

Work motivation drives employees to perform congruently with the organizations' objectives. It is obvious from the model that work motivation is a key factor influencing the employees' intention to leave organization through both job performance and job satisfaction. So, it is important to manage this growing risk of employee turnover in the public sector organization through assessing impacts of those factors. A range of research has been conducted to explore and model theories of work motivation. For example, the plethora of theories on motivation proposed an integrative context mainly based on a chronological order of motivation (e.g., see Locke 1991). While, some researchers considered the 1960s and 1970s to be the "golden age" of work motivation theory because of the considerable advances in our understanding of the concept that were made during this period (Steers et al. 2004).

According to the study by Locke (1991), motivational theories can be classified into a group of seven elements such as 'needs', 'values', 'goals', 'expectancy and self-efficacy', 'performance', 'rewards', and 'satisfaction'. Locke explained the elements as follows.

Needs: "The concept of need explains why living organism act". Theories of motivation based on needs include Maslow's hierarchy of needs theory and Deci's self-determination theory.

Values: In contrast to needs, which are innate, values are in consciousness and acquired. Values are the connection between needs and action. Locke included McClelland's need for achievement theory, Miner's role motivation theory, and Vroom's expectancy theory within this element.

Goals: The reflection of the person's values are found in the goals they set. Goals are defined as applications of values to specific situations. Goal theory (Locke and Latham 1990) explains how goals affect action by affecting the intensity, duration, and direction of action. 
Expectancy and self-efficacy: These two concepts influence the process of setting up goals. The motivational theories which are included in this category are expectancy theory and social-cognitive theory (Locke 1991).

Performance: Goals and self-efficacy are considered as the most immediate and direct motivational determinants of performance. Typical attribution theory explains people's attribution on their performance and how such attributions affect subsequent passions and actions.

Rewards: People's action or performance are driven by rewards and therefore rewards can modify people's behaviour. Motivational theories which focused on rewards are behaviour modification theory and the equity theory.

Satisfaction: Some theories explain the relation between work and job satisfaction. These include Herzberg's two-factor (motivation-hygiene) theory, Hackman and Oldham's job characteristics theory, and Locke's satisfaction theory.

In the above framework, the researcher has emphasized values as the motivation core, because values are the keys that make every individual as unique and guide them to real choices and effective actions. Values and rewards has a strong correlation as well. Locke (1991) motivation sequence framework also indicates that goals, self-efficacy, and performance are important motivational core, which determines the individual's activities.

In an alternative review on motivational theories Steers et al. (2004) classified motivation theory into two groups: content theory and process theory. Factors that regulate and manage individual and social behaviour can be explained by content theory such as the motivation-hygiene theory (Herzberg et al. 1962). The motivation-hygiene theory proposes two types factors (Herzberg 1974) which are: (1) motivation factors such as achievement (i.e., a job itself will give an employee a sense of stimulated feeling of having done something worthwhile), recognition (i.e., an employee will be well recognized and/or praised for each of their successes by the supervisors and colleagues), responsibility (i.e., an employee must take responsibility of their job task with ownership to complete the task), growth (i.e., an employee should get opportunity to learn new skills through professional development and/or formal educational training), advancement (i.e., an employee should get an equal opportunity to be promoted at a higher level), and tasks in the occupation (i.e., everyday tasks in the work must be inspiring, diverse, and/or offer a good range of creative challenges); and (2) hygiene factors such as salary (i.e., a fair and reasonable salary structure which must be expediently competitive with other institutes within the same business domain), status and security (i.e., an employee should have a solid status in the organization and feel secure about their job without any significant risk of being jobless), supervision (i.e., an employee should get fair and appropriate supervision with their independence to do better and grow), relationship (i.e., an employee should work in a healthy, functional, and cooperative and collegial workplace without any bullying or cliques), work conditions (i.e., workplace environment and tools must be contemporary, safe, functional, and hygienic), and company policies (i.e., all policies need to be open, fair and equivalent for everyone within the company and their competitors). Over time, these concepts in motivation factors and hygiene factors have evolved into the terms "intrinsic motivation" and "extrinsic motivation", respectively. This theory and terms have been widely applied in many literature (e.g., Carmeli and Weisberg 2006; Furnham et al. 2009; Maidani 1991; Park et al. 1988; Sachau 2007; Smith and Shields 2013).

Typically, intrinsic motivation is related with job content, while later is correlated with extrinsic motivation. According to Herzberg (1974), achievement, recognition for achievement, job itself, responsibility, growth and advancement are intrinsic motivation factors, whereas, policy and administration of the organization, supervision strategies, interpersonal relationship between employees, workplace environments and conditions, job status, salary, and work security are extrinsic motivation factors. Given that intrinsic motivation was positively associated with job satisfaction, Herzberg proposed a technique of job enrichment through increasing intrinsic motivation to make jobs more interesting. Later on the work of Hackman and Oldham (1976), in developing the job 
characteristics model, which advocated work redesign or job enlargement, was strongly influenced by the motivation-hygiene theory.

Others argued that extrinsic motivation also contributes to job satisfaction. This debate gave rise to the initial use of the terms intrinsic motivation and extrinsic motivation as explained by Sachau (2007). When people work to fulfil hygiene needs they are responding to extrinsic motivation. That is, they are moved to act by life factors external to the job. Intrinsic motivation, on the other hand, refers to factors that influence work behaviour that are directly related to the nature of the work itself. Thus, when Herzberg controversially wrote that "money is not a motivator" (see p. 381), he was not saying that money could not move people to work. He was arguing that money was not an intrinsic motivator, but rather an extrinsic motivator as its value lay in its ability to acquire the goods and services on which life and life-style were based.

A similar distinction between intrinsic and extrinsic motivation was proposed by Ryan and Deci (2000) in developing their self-determination theory (SDT). Here, intrinsic motivation was defined as "the doing of an activity for its inherent satisfactions rather than for some separable consequences" (p. 56). Extrinsic motivation was defined as "a construct that pertains whenever an activity is done in order to attain some separable outcome" (p. 60). Moreover, their study identified four stages, external regulation, introjection, identification, and integration, though which extrinsic motivation is transformed into intrinsic motivation. The most autonomous form of extrinsic motivation is integration, i.e., a complete blending of external drivers and self-values for a particular action.

Debate has arisen over the potential impact of extrinsic rewards on intrinsic motivation with the view emerging that extrinsic rewards may weaken intrinsic motivation. Empirical research, however, is inconclusive. Following a meta-analytic study Wiersma (1992) noted that "it is not supported when task performance is measured while the extrinsic reward is in effect". On the other hand Deci et al. (1999), based on a meta-analysis of 128 past experiments, claimed that "tangible rewards tend to have a substantially negative effect on intrinsic motivation".

Finally, in considering work motivation for the public sector, we must ask if the motives that drive people to serve in public or community development are likely to be different to those in non-public sector occupations. Perry and Wise (1990) asserted that there exists a public service motivation (PSM) which can be defined as "an individual's predisposition to respond to motives grounded primarily or uniquely in public institutions and organizations" (see p. 368). Building on this, Perry and Hondeghem (2008) argued that public service motivation is composed of "individual motives that are largely, but not exclusively, altruistic and are grounded in public institutions" (refer to pp. 3-4). Perry (1997) also investigated the antecedents of public service administration, and proposed five sets of correlates: parental socialization, religious socialization, professional identification, political ideology, and individual demographics.

The work of Vandenabeele $(2007,2008,2011)$ explained the theoretical framework of PSM, provided a measurement scale for PSM, and identified the antecedent of PSM which was related to the institutional development of PSM. Vandenabeele (2007) proposed a hypothetical framework that positioned PSM within the theories of institutionalism, SDT, and the person-organization fit theory. It assumed that "the degree of institutions respond to the individual psychological needs of relatedness, competence and autonomy, institutionalized public service values will be internalized more autonomously in the individual identity" (p. 553). Furthermore, he hypothesized "to the degree that a public service identity is more autonomous, it will result in a more consistent and intense public service behaviour, given that the institution in which the individual operates embraces the public service values" (p. 553). However, Vandenbeele acknowledged that further research was require to provide empirical validity to his theory.

In existing public administration literature, PSM has been considered as one of the key research topics at both national and international levels (Bright 2013). As the study of Pedersen (2013) confirmed that the PSM dimension of "public interest" was positively associated with attraction to public sector employment, as a support for one of Perry and Wise (1990) propositions. 


\section{Examining Relationship between Work Motivations and Job Performance and Job Satisfaction}

The key three links between work motivation and job performance, work motivation and job satisfaction, and job performance and job satisfaction are examined in this section in line with the evidences from the literature. Although there is a range of studies available in this area of research which primarily focused on private sector, our focus here is on the public sector. Therefore, we will mainly rely on most of the resources from the public sector research which are consistent to validate our analysis.

\subsection{Relationship between Work Motivations and Job Performance}

Herzberg (1968) examined the relationship between work motivation and job performance by comparing a group of workers who had been enriched with motivator factors (intrinsic motivations which included achievement, responsibility, recognition, growth, and learning) with a control group. He observed that the test group had better performance and attitudes towards their job than the control group and concluded that motivator factors (intrinsic motivation) had a positive relationship to job performance.

With respect to extrinsic motivations, Sachau (2007) adopted Herzberg's notion that "hygiene factors have an escalating zero point" (see p. 386). That is "once a person has experienced a new higher level of a given hygiene factor, the new level becomes the minimal acceptable level".

Thus, both intrinsic and extrinsic motivations have been identified as critical factors driving job performance. Studies have consistently reported a positive relationship between job performance and intrinsic motivation (Dysvik and Kuvaas 2010, 2013; Grant 2008; Joo et al. 2010). Similarly, research generally supports the presumption that extrinsic rewards (a form of extrinsic motivators) will be positively related to job performance (Bonner and Sprinkle 2002; Condly et al. 2003; Dysvik and Kuvaas 2013; Garbers and Konradt 2014). However, some authors warn that findings with respect to extrinsic rewards should be used prudently—especially in relation to task complexity.

With respect to public service organizations, Perry and Wise (1990) proposed that

(1) A higher level of PSM of an individual is favourable to join a public sector organization;

(2) PSM is positively correlated with job performance; and

(3) Individual employees' performance can be easily managed if the public sector organizations appoint workforce having a higher level of PSM.

Subsequent studies have provided empirical validation of these hypotheses (see Naff and Crum 1999; Alonso and Lewis 2001; Bright 2007). While the first two of these three studies found a significantly positive relationship between PSM and job performance, the third study added to it by showing that the relationship was stronger when person-organization $(\mathrm{P}-\mathrm{O})$ fit was introduced as a mediating factor.

Vandenabeele (2009) undertaking research in public sector organizations in Belgium, confirmed that PSM was significantly related to job performance (as well as to both job satisfaction and organizational commitment). Further, research with Italian nurses (Bellé 2013) found that individuals with higher PSM had stronger job performance. Interestingly, Bellé (2013) also argued that "PSM is a dynamic state" and "the levels of PSM found among an organization's employees may be not wholly determined by attraction-selection-attrition mechanisms but may also be influenced by the organization to some extent".

\subsection{Relationship between Work Motivation and Job Satisfaction}

The motivation-hygiene theory is frequently used in contemporary research. Several studies have revealed that both work motivation and hygiene factors have positive relationship with employees' job satisfaction (e.g., Furnham et al. 2009; Islam et al. 2011; Sell and Cleal 2011; Smith and Shields 2013).

A sample of 107,292 observations from 49 countries has been used in a study by Huang and Vliert (2003), which reveals that various extrinsic job characteristics have a strong and significant relationship 
with job satisfaction in all countries. It also demonstrates that the strength of correlation is higher for data from richer countries, having better social security, more individualistic values, and relatively a less power distance culture.

Moreover, a study on job satisfaction in West Germany, Great Britain, the United States, Hungary, Norway, and Israel has revealed that there is a positive and statistically significant associations of both intrinsic and extrinsic rewards, relationships with administration and work-relations with colleagues to job satisfaction (Westover and Taylor 2010). However, intrinsic rewards were found to have the dominant influence. Furthermore, PSM was found to have an insignificant impact on job satisfaction, although PSM-fit proved to be significant. Counteracting this finding was the work of Taylor and Westover (2011). They used the same survey (the International Social Survey Program, ISSP), but chose different countries (the USA; Canada; Great Britain; Germany; France; Denmark; and Norway), and found that PSM was significantly related to job satisfaction in government employees.

\subsection{Relationship between Job Satisfaction and Job Performance}

The relationship between employees' job satisfaction and job performance remains a very important topic in organizational risk management processes. It is generally held that job satisfaction has an insignificant impact on job performance. Lawler and Porter (1967) cite the Brayfield and Crockett (1955) review study on this issue in which they conclude "there is little evidence in the available literature that employee attitudes bear any simple relationship to performance on the job" (see p. 21). This conclusion has resulted in the issue being frequently re-examined.

Lawler and Porter (1967) demonstrate that there is a positive and persistent relationship between job satisfaction and job performance. They stated that "satisfaction is an important variable from both a theoretical and a practical point of view despite its low relationship to performance" (see p. 24). Locke (1970), who took into consideration motivational theories (including expectancy theory, goal-setting theory, and achievement theory) inferred that "the effect of performance on satisfaction is viewed as a function of the degree to which performance entails or leads to the attainment of the individual's important job values".

Iaffaldano and Muchinsky (1985) concluded that job satisfaction had an insignificant impact on job performance. Judge et al. (2001), on the other hand, found a high and significant correlation and declared that it was "premature to dismiss the relationship" (see p. 389). They encouraged future research on the issue-proposing an integrative model of the relationship between job satisfaction and job performance (see p. 390).

This call was answered by Schleicher et al. (2004) who found a larger and significant correlation had existed between job satisfaction and job performance when moderated by affective-cognitive consistency. Subsequently Borgogni et al. (2010) confirmed "job satisfaction affects job performance, along with the organizational tenure" (refer to p. 288). Finally, Nyberg (2010) concluded that "performance was statistically significant and positively associated with job satisfaction". Therefore, our proposed model considers these two factors as the mediating factors of the development of the intention to leave an organization from the overall work motivation.

\section{Determinants of the Intention to Leave an Organization}

It can be very costly for an organization when its highly competent employees may have voluntary disengagement to the organization's perspectives. So, this organizational risk to me managed effectively specially in the public sector as it is a growing concern for many countries. According to a study by Hellman (1997), typical risks include employee replacement costs as well as operational disruptions. Often the individuals' perception of their prospects for generating a higher level income from private sector organizations can drive to leaving a public sector organizations. There is extensive research into turnover intentions, (e.g., see Bluedorn 1982b; Swailes and Fahdi 2011; Carmeli and Weisberg 2006; Nyberg 2010). 
A meta-analysis by Zimmerman and Darnold (2009) concluded that the relationship between job performance and intention to quit is "both negative and modest". It was also recognized that the relationship could be mediated by other factors, such as job satisfaction. Nyberg (2010) on the other hand, concluded "the negative relationship between performance and voluntary turnover was stronger when pay growth was high than when pay growth was low" (see p. 449). This result implied that the high performers were more likely to stay within the organization when pay growth was high. A similar finding was associated with the prevalence of promotion prospects. High performing employees were found to have a higher propensity to voluntarily resign when the unemployment rate rose, as they believed that they could seize the better opportunities in a competitive labour market than the lower performing employees.

Typically, a low level job satisfaction is connected to a turnover intention. For instances, A recent study by Mihajlov and Mihajlov (2016) has revealed that public sector employees have higher extrinsic job satisfaction and lower turnover intentions compared to their counterparts in the private sector. Job satisfaction affects organizational commitment, which then successively effects intention to leave organization (Bluedorn 1982b), and job satisfaction and affective commitment have been significantly related to turnover intentions (Carmeli and Weisberg 2006). Another research also demonstrates that job satisfaction was a statistically significant mediator of performance-voluntary turnover relationship (Nyberg 2010, p. 449). These findings are repeated in several studies (Hellman 1997; Tett and Meyer 1993; Griffeth et al. 2000; Hom and Kinicki 2001; Chen et al. 2011).

Finally, Tett and Meyer (1993) conducted a path analyses based on meta-analytic findings of the relationships between job satisfaction, organizational commitment, and turnover. They found that job satisfaction had a high negative correlation with turnover intention and that this impact was stronger than that of organization commitment. So, the overall findings suggest that job satisfaction is one of the best predictive measurement of employees' intention to leave the organization, which is in consistent with the funding in other research (e.g., Griffeth et al. 2000).

\subsection{The Public Sector Context}

Our goal in this paper is to examine the influence of work motivation, job performance, and job satisfaction on the intention to leave an organization-especially in the contexts of the public sector organizations and the risk management in public sector. Employee voluntary turnover has been an important issue of both practical and theoretical significance. Voluntary turnover could be driven by many factors, such as low job satisfaction, poor individual or organizational performance, or external factors (i.e., unemployment rate).

Public sector management has evolved over the last three decades. In this 21st century's business environment, the public sector organization need a higher level of accountability and transparency than in the past century. Research and innovations in public administration and new public management concepts can be useful to meet this progressive demand. A relevant example could be the Organization for Economic Co-operation Development (OECD), which has pushed reform agendas to its member countries. Moreover, governments in many countries have already launched public sector organizational reform to tackle their internal social and economic crises or meet to international demand and standards.

Therefore, in the globalized services providing environments public sectors' financial organizations are in a huge challenge to reform and provide better outcomes and performance to local, national and international communities. When an organization is under reform, it employees not only face with changes related to their job design, salary arrangements, and performance appraisal system, but also they must meet specific performance target at individual and organizational levels. They require appropriate professional developments to equip themselves with high levels of work motivations to accomplish and align themselves to their organizational targets. The professional development opportunities may be limited in many public sector organization. As a result, a high proportion 
of employees may consider voluntary turnover, which will eventually disrupt performance of the organization to meet its functional objectives.

Highly motivated employees are valuable assets for organizations. Employees could be motivated by intrinsic and extrinsic factors. Interestingly, comparison studies on motivation and job satisfaction between public and private sectors have shown mixed results. Some have resulted in no significant differences in intrinsic motivation in either sector, but an important impact in the public sector for extrinsic motivation (Maidani 1991). Other researchers have found no significant disparities between private and public sectors (DeSantis and Durst 1996). While, a study of data from 51 countries revealed that employees of 21 countries (out of the 51 countries) have a higher intrinsic motivation in the public sector than the private sector (Cowley and Smith 2014). Table 1 presents the results of a comparative research between the public sector and private sector organizations on the topic of work motivation, job performance, job satisfaction, and intention to leave the organization. Although the table includes several selected studies from the public sector context, our discussion covers other relevant research which follows.

Table 1. A comparative study between public sector and private sector research on work motivation, job performance, job satisfaction, and turnover intention.

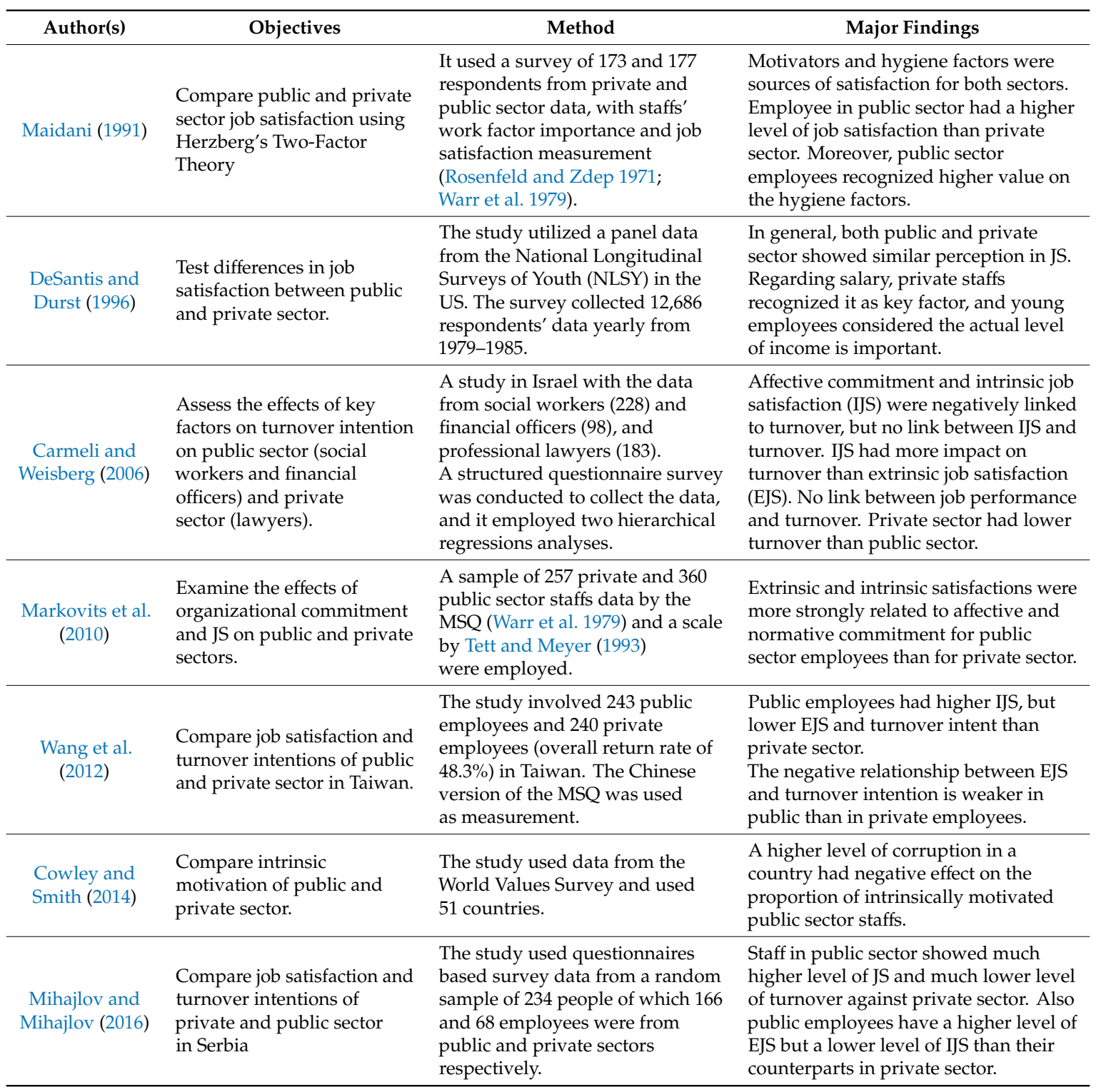


Findings reveal that intrinsic motivation has a statistically significant and positive link to an employee's job satisfaction (Carmeli and Weisberg 2006; Markovits et al. 2010; Cho and Perry 2012). Extrinsic motivation has also a positive relationship to the public sector motivation (Wang et al. 2012; Taylor and Taylor 2011). Additionally, people are attracted to the public sector organizations by their intrinsic rewards rather than their extrinsic rewards (Markovits et al. 2010; Georgellis et al. 2011). In other words, a higher level of extrinsic gains reduce the propensity of intrinsically motivated employees to involve in public sector organization (Mihajlov and Mihajlov 2016).

Additionally, in line with the sector characteristics, individuals might consider public sector occupation if they have high public service motivation (Perry and Wise 1990). Anderfuhren-Biget et al. (2010) examined the influence of PSM on work motivation in the public sector in Switzerland. Their study convincingly supported the inclusion of PSM as an important motivational factor in the public sector. Another study of PSM in the Australian public sector (Taylor 2007) confirmed that employees with higher levels of the four dimensions of PSM were more likely to show higher levels of organizational commitment, job motivation, and job satisfaction. Taylor and Westover (2011) investigated and compared the effects of a selection of antecedents related to job satisfaction in government employees in the USA; Canada; Great Britain; Germany; France; Denmark; and Norway. They reported that job satisfaction was significantly related to PSM, extrinsic workplace attributes, intrinsic workplace attributes, work relations with managers and work relations with co-workers. A more recent study by Taylor (2014) examined the relationship between PSM, job design, and job satisfaction in Australian local government, and concluded that government employees with a high level of PSM were more satisfied, particularly when they could observe the positive impact of their job to the community. Mihajlov and Mihajlov (2016) found somewhat a consistent finding in Serbia that a high level of PSM including extrinsic satisfaction can be derived from fundamental cultural values, close and harmonious relationships with supervisors and peers, and open information sharing within the corporation which reducing their fear and insecurity, and nurture strong bond with the corporation. Other studies also examined PSM in a non-western cultural context (Prihandinisari et al. 2016) and analyzed the effects of knowledge management (KM) and human resource management (HRM) processes to the performance organization and employee's job satisfaction (Rahman and Hasan 2017).

To conclude, these findings demonstrate that public sector context is an important area of research due to ever changing globally connected business environment, and demand for a higher level of accountability and transparency which must be competitive to the advanced private sector. It is interesting to note that in addition to the public sector motivation, both intrinsic and extrinsic motivation of public sector employees are crucial to maintain satisfactory levels of job performance and job satisfaction. These will ultimately contribute to employees' turnover intention including voluntary turnover from the public sector.

\subsection{Turnover Intention in the Public Sector}

It is only in the last few years that public administration scholars have begun exploring the question of job turnover in the public sector. The issues considered in these research have included the determinants of employee turnover (Bertelli 2007), administrative employees turnover (Bertelli 2007; Boyne et al. 2010; Bertelli and Lewis 2013), comparison of public and private sectors employees turnover (Carmeli and Weisberg 2006; Wang et al. 2012), examining link between employees turnover and their gender (Moynihan and Landuyt 2008; Grissom et al. 2012), individual and organization fit (Moynihan and Pandey 2008), analyzing organizational goals (Jung 2014), and employees and organization performance (Meier and Hicklin 2008; Lee and Jimenez 2011). Moreover, there are many research studies on turnover intention are related to job satisfaction though (e.g., Carmeli and Weisberg 2006; Bright 2008; Liu et al. 2010; Pitts et al. 2011; Grissom et al. 2012; Wang et al. 2012). Table 2 presents a summary of the findings from relevant research. 
Table 2. Summary of research on turnover intention in public sector.

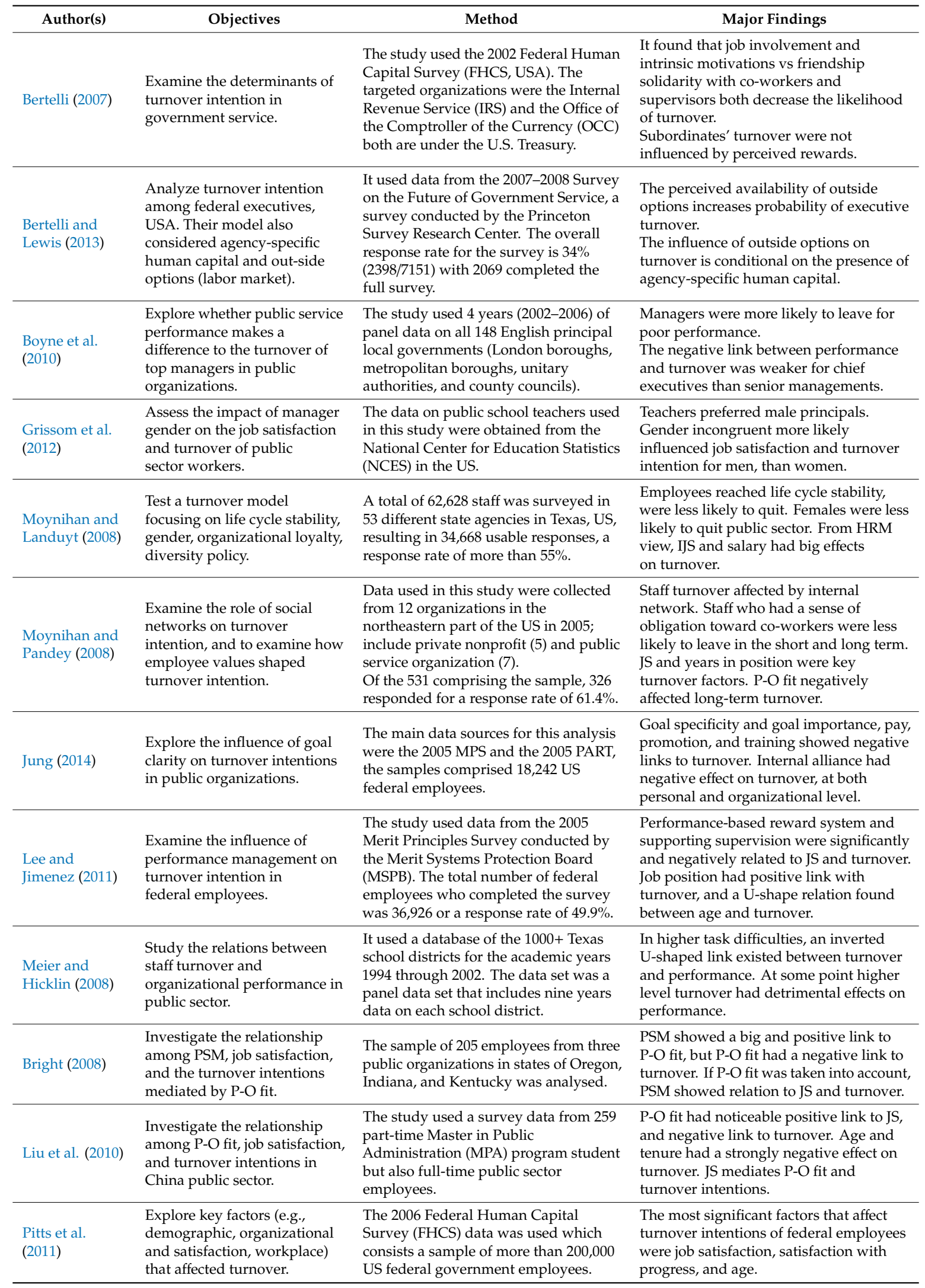


Results demonstrate that the employee turnover intention might have a negative or positive impacts on organizational performances (Bluedorn 1982b; Meier and Hicklin 2008; Lee and Jimenez 2011). Typically, the negative effects encompass expenditures related to new staff recruitment, drop in productivity and reduced self-esteem in existing workers. There is also a functional impacts which imply the positive values of employee turnover intention, especially when the leaving workers are a low level performers. In such situations, the organization can get advantage from appointing some highly skilled new employees. In most cases, a new staff will usually come advanced ideas and bring better innovations in the organization.

The relationship between job performance and intention to leave could be positive, negative, a non-linear relationship, or not significant (Allen and Griffeth 1999; Carmeli and Weisberg 2006; Meier and Hicklin 2008; Zimmerman and Darnold 2009). The mixed findings in the literature on the relationship between job performance and turnover intention leaves a gap that should be addressed empirically to gain a better understanding and validation of the issue. By gaining better knowledge around these factors, public sector organization should be able to manage the employee turnover risk effectively.

As already mentioned above, most studies of turnover intention are related to job satisfaction. Hellman (1997) meta-analysis reported that "the relationship between job satisfaction and intention to leave was significantly different from zero and consistently negative". This conclusion was reached following the analysis of 50 studies between 1983 and 1993. The study took into consideration the relations of the variables amongst federal government employees. The study also revealed that federal government employees were less likely to leave the organizations than the private sector employees. However, the meta-analysis is limited to studies in the USA context.

Naff and Crum (1999) found that government employees with high PSM had higher job satisfaction and were less likely to leave their organizations. However, the PSM-job satisfaction-turnover intention relationships became insignificant when person-organization fit was introduced as a mediating factor (Bright 2008). Again, however, both studies were conducted in the USA. The studies of job satisfaction relationship to turnover intention in the public sector outside of those conducted in the USA include Liu et al. (2010) for China, Wang et al. (2012) for Taiwan, Carmeli and Weisberg (2006) for Israel; and Hwang and Chang (2008) for Korea.

The apparent mixed results concerning the relationship between turnover intention and both job satisfaction and job performance must be given serious consideration. Additional considerations that need to be addressed are whether higher performing employees have higher job satisfaction; whether or not high job satisfaction leads to high performance; and, if so, whether their high satisfaction rates result in the high performing employees staying in their organizations.

Additionally, as we observe, most of the public administration literature considers only developed western countries (mainly in the US context). It will therefore be interesting to study how work motivation, job performance and job satisfaction influence the employees' turnover intention in a recently reformed public sector financial organization of a developing country in Asia.

\section{Conclusions}

This paper has reviewed both organizational literature and public administration literature on turnover intention, and its relationship to both job performance and job satisfaction. It has also considered the impact of work motivations-including theoretical framework and empirical findings. The paper has offerred a explanatory risk management model which integrates work motivations (intrinsic and extrinsic motivations, and public service motivation), job satisfaction, and job performance, and the interplay between those factors in shaping public sector employee's turnover intention. Findings reveal that employee turnover is a considerable risk to manage in the public sector in many countries including developing countries in Asia.

It is evidenced in the findings that job satisfaction has a negative and significant relationship with the intention to leave an organization. Subsequently, employees' satisfaction is more likely built up from 
intrinsic and extrinsic motivation factors, as positive correlations have shown in most of the findings. This relation is also found in most PSM studies. Interestingly, the relationship between job performance and intention to leave has been diversely reported, as it could be positive, negative, a non-linear relationship, or not significant. However, research generally confirms a positive relationship between job performance and work motivations, including intrinsic motivation, extrinsic motivation, and PSM.

Another key point emanating from the results is the interplay between job performance and job satisfaction. Again, mixed results are reported. Some research indicates that employee satisfaction leads to better job performance On the other hand, other research suggests that higher job satisfaction was caused by higher levels of performance. Nevertheless, both groups agree that positive correlations exist.

It is important to note that most of the research on the public sector turnover intention has been from developed-western countries (the USA and European countries); or developed and non-western countries (Australia, New Zealand, and China). Some of the studies also employed a pre-existing data set derived from governmental survey or international survey organizations, leaving a question of reliability.

In conclusion, as the paper aimed to empirically examine the nexus between three key factors and their influences on employees' turnover intention in order to effectively manage this organizational risk, there was no specific methodology section provided. Our proposed explanatory risk management model is based on both traditional and contemporary concepts in the research though which has been descriptively validated with the existing research. Our motivation was to develop this conceptual risk management model for advancing it to a further application paper which will provide details of mixed methods, i.e., both qualitative and quantitative approaches to validate our model further with application to real world data from an Asian country. Moreover, considering many mixed research outputs in the topics, the proposed model could serve as a guideline for future research in public sector research. Further research should be directed at answering the questions such as to what extent do work motivation, job performance, and job satisfaction influences the intention to leave the public service? In this setting, PSM should be considered a critical work motivation in the public sector along with intrinsic and extrinsic motivations. Future research on these topic should also take into account the context of the study, such as in a developing and non-western country, a reformed organization, and possibly experiencing a high voluntary turnover. Studies of this type should be addressed to clarify our understanding of the importance of turnover intention in the public sector.

Author Contributions: Conceptualization, C.P.; A.R.; Methodology, A.R.; Formal Analysis, C.P.; Data Curation, C.P.; A.R.; Writing-Early Draft Preparation, C.P.; Writing-Review and Editing, A.R.; J.H. Supervision, A.R.; J.H. Project Administration, A.R. All authors have read and agreed to the published version of the manuscript.

Funding: This research received no external funding.

Acknowledgments: The authors would like to thanks the editors and three anonymous reviewers for their valuable insightful comments and stimulus which were used to form this final version. We would also like to acknowledge the editing support provided by the Data Science Research Unit at the Charles Sturt University, Australia.

Conflicts of Interest: The authors declare no conflict of interest.

\section{References}

Allen, David, and Rodger Griffeth. 1999. Job Performance and Turnover: A Review and Integrative Multi-Route Model. Human Resource Management Review 9: 525-48. [CrossRef]

Alonso, Pablo, and Gregory Lewis. 2001. Public Service Motivation and Job Performance: Evidence from the Federal Sector. The American Review of Public Administration 31: 363-80. [CrossRef]

Anderfuhren-Biget, Simon Varone, Frederic Giauque David, and Adrian Ritz. 2010. Motivating Employees of the Public Sector: Does Public Service Motivation Matter? International Public Management Journal 13: $213-46$. [CrossRef]

Bellé, Nicola. 2013. Experimental Evidence on the Relationship between Public Service Motivation and Job Performance. Public Administration Review 73: 143-53. [CrossRef] 
Bertelli, Anthony. 2007. Determinants of Bureaucratic Turnover Intention: Evidence from the Department of the Treasury. Journal of Public Administration Research and Theory 17: 235-58. [CrossRef]

Bertelli, Anthony, and David Lewis. 2013. Policy Influence, Agency-Specific Expertise, and Exit in the Federal Service. Journal of Public Administration Research and Theory 23: 223-45. [CrossRef]

Bluedorn, Allen. 1982a. A unified model of turnover from organizations. Human Relations 35: 135-53. [CrossRef] Bluedorn, Allen. 1982b. Managing turnover strategically. Business Horizons 25: 6-12. [CrossRef]

Bonner, Sarah, and Geoffrey Sprinkle. 2002. The effects of monetary incentives on effort and task performance: Theories, evidence, and a framework for research. Accounting, Organizations and Society 27: 303-45. [CrossRef]

Borgogni, Laura, Dello Russo Salvia, Laura Petitta, and Michele Vecchione. 2010. Predicting job satisfaction and job performance in a privatized organization. International Public Management Journal 13: 275-96. [CrossRef]

Boswell, Wendy, John Boudreau, and Jan Tichy. 2005. The relationship between employee job change and job satisfaction: The honeymoon-hangover effect. Journal of Applied Psychology 90: 882-92. [CrossRef]

Boyne, George, Oliver James, Peter John, and Nicolai Petrovsky. 2010. Does Public Service Performance Affect Top Management Turnover? Journal of Public Administration Research and Theory 20: i261-i279.

Brayfield, Arthur, and Walter Crockett. 1955. Employee attitudes and employee performance. Psychological Bulletin 52: 396-424. [CrossRef] [PubMed]

Bright, Leonard. 2007. Does Person-Organization Fit Mediate the Relationship Between Public Service Motivation and the Job Performance of Public Employees? Review of Public Personnel Administration 27: 361-79. [CrossRef]

Bright, Leonard. 2008. Does public service motivation really make a difference on the job satisfaction and turnover intentions of public employees? The American Review of Public Administration 38: 149-66. [CrossRef]

Bright, Leonard. 2013. Where Does Public Service Motivation Count the Most in Government Work Environments? A Preliminary Empirical Investigation and Hypotheses. Public Personnel Management 42: 5-26. [CrossRef]

Carmeli, Abraham, and Jacob Weisberg. 2006. Exploring turnover intentions among three professional groups of employees. Human Resource Development International 9: 191-206. [CrossRef]

Chen, Gilad, Robert Ployhart, Helena Cooper Thomas, Neil Anderson, and Paul Bliese. 2011. The power of momentum: A new model of dynamic relationships between job satisfaction change and turnover intentions. Academy of Management Journal 54: 159-81. [CrossRef]

Chiu, Randy, and Anne Marie Francesco. 2003. Dispositional traits and turnover intention. Examining the mediating role of job satisfaction and affective commitment. International Journal of Manpower 24: 284-98. [CrossRef]

Cho, Yoon Jik, and James Perry. 2012. Intrinsic motivation and employee attitudes: Role of managerial trustworthiness, goal directedness, and extrinsic reward expectancy. Review of Public Personnel Administration 32: 382-406. [CrossRef]

Condly, Steven, Richard Clark, and Harold Stolovitch. 2003. The Effects of Incentives on Workplace Performance: A Meta-analytic Review of Research Studies. Performance Improvement Quarterly 16: 46-63. [CrossRef]

Cowley, Edd, and Sarah Smith. 2014. Motivation and mission in the public sector: Evidence from the World Values Survey. Theory and Decision 76: 241-63. [CrossRef]

de Moura, Georgina Randsley, Dominic Abrams, Carina Retter, Sigridur Gunnarsdottir, and Kaori Ando. 2009. Identification as an organizational anchor: How identification and job satisfaction combine to predict turnover intention. European Journal of Social Psychology 39: 540-57. [CrossRef]

Deci, Edward, Richard Ryan, and Richard Koestner. 1999. A meta-analytic review of experiments examining the effects of extrinsic rewards on intrinsic motivation. Psychological Bulletin 125: 627-68. [CrossRef] [PubMed]

Delobelle, Peter, Jakes Rawlinson, Sam Ntuli, Inah Malatsi, Rika Decock, and Anne Marie Depoorter. 2011. Job satisfaction and turnover intent of primary healthcare nurses in rural south africa: A questionnaire survey. Journal of Advanced Nursing 67: 371-83. [CrossRef] [PubMed]

DeSantis, Victor, and Samantha Durst. 1996. Comparing job satisfaction among public- and private-sector employees. The American Review of Public Administration 26: 327-43. [CrossRef]

Dysvik, Anders, and Bard Kuvaas. 2010. Intrinsic motivation as a moderator on the relationship between perceived job autonomy and work performance. European Journal of Work and Organizational Psychology 20: 367-87. [CrossRef]

Dysvik, Anders, and Bard Kuvaas. 2013. Intrinsic and extrinsic motivation as predictors of work effort: The moderating role of achievement goals. British Journal of Social Psychology 52: 412-30. [CrossRef] 
Ellett, Alberta, Jacquelyn Ellis, Tonya Westbrook, and Denise Dews. 2007. A qualitative study of 369 child welfare professionals' perspectives about factors contributing to employee retention and turnover. Children and Youth Services Review 29: 264-81. [CrossRef]

Furnham, Adrian, Andreas Eracleous, and Tomas Chamorro-Premuzic. 2009. Personality, motivation and job satisfaction: Hertzberg meets the Big Five. Journal of Managerial Psychology 24: 765-79. [CrossRef]

Garbers, Yvonne, and Udo Konradt. 2014. The effect of financial incentives on performance: A quantitative review of individual and team-based financial incentives. Journal of Occupational and Organizational Psychology 87: 102-37. [CrossRef]

Georgellis, Yannis, Elisabetta Iossa, and Vurain Tabvuma. 2011. Crowding Out Intrinsic Motivation in the Public Sector. Journal of Public Administration Research and Theory 21: 473-93. [CrossRef]

Grant, Adam. 2008. Does Intrinsic Motivation Fuel the Prosocial Fire? Motivational Synergy in Predicting Persistence, Performance, and Productivity. Journal of Applied Psychology 93: 48-58. [CrossRef] [PubMed]

Griffeth, Rodger, Peter Hom, and Stefan Gaertner. 2000. A meta-analysis of antecedents and correlates of employee turnover: Update, moderator tests, and research implications for the next millennium. Journal of Management 26: 463-88. [CrossRef]

Grissom, Jason, Jill Nicholson-Crotty, and Lael Keiser. 2012. Does my boss's gender matter? Explaining job satisfaction and employee turnover in the public sector. Journal of Public Administration Research and Theory 22: 649-73. [CrossRef]

Hackman, Richard, and Greg Oldham. 1976. Motivation through the design of work: Test of a theory. Organizational Behavior and Human Performance 16: 250-79. [CrossRef]

Hellman, Chan. 1997. Job satisfaction and intent to leave. The Journal of Social Psychology 137: 677-89. [CrossRef]

Herzberg, Frederick. 1968. One more time: How do you motivate employees? Harvard Business Review 81: 87-96.

Herzberg, Frederick. 1974. Motivation-hygiene profiles: Pinpointing what ails the organization. Organizational Dynamics 3: 18-29. [CrossRef]

Herzberg, Frederick, Bernard Mausner, and Barbara Bloch Snyderman. 1962. The Motivation to Work, 2nd ed. New York: Wiley.

Hom, Peter, and Angelo Kinicki. 2001. Toward a greater understanding of how dissatisfaction drives employee turnover. Academy of Management Journal 44: 975-87. [CrossRef]

Huang, Xu, and Evert Van De Vliert. 2003. Where intrinsic job satisfaction fails to work: National moderators of intrinsic motivation. Journal of Organizational Behavior 24: 159-79. [CrossRef]

Hwang, Jee-In, and Hyejung Chang. 2008. Explaining turnover intention in Korean public community hospitals: Occupational differences. The International Journal of Health Planning and Management 23: 119-38. [CrossRef]

Iaffaldano, Michelle, and Paul Muchinsky. 1985. Job Satisfaction and Job Performance. A Meta-Analysis. Psychological Bulletin 97: 251-73. [CrossRef]

Islam, Jesmin, Quazi Ali, and Azizur Rahman. 2011. Nexus between cultural dissonance, management accounting systems, and managerial effectiveness: Evidence from an asian developing country. Journal of Asia-Pacific Business 12: 280-303. [CrossRef]

Joo, Baek-kyoo, Chang-Wook Jeung, and Hea Jun Yoon. 2010. Investigating the influences of core self-evaluations, job autonomy, and intrinsic motivation on in-role job performance. Human Resource Development Quarterly 21: 353-71. [CrossRef]

Judge, Timothy, Carl Thoresen, Joyce Bono, and Gregory Patton. 2001. The job satisfaction-job performance relationship: A qualitative and quantitative review. Psychological Bulletin 127: 376-407. [CrossRef] [PubMed]

Jung, Chan Su. 2014. Why Are Goals Important in the Public Sector? Exploring the Benefits of Goal Clarity for Reducing Turnover Intention. Journal of Public Administration Research and Theory 24: 209-34. [CrossRef]

Lambert, Eric, and Nancy Hogan. 2009. The Importance of Job Satisfaction and Organizational Commitment in Shaping Turnover Intent: A Test of a Causal Model. Criminal Justice Review 34: 96-118. [CrossRef]

Lawler, Edward, and Lyman William Porter. 1967. The effect of performance on job satisfaction. Industrial Relations: A Journal of Economy and Society 7: 20-28. [CrossRef]

Lee, Geon, and Benedict Jimenez. 2011. Does Performance Management Affect Job Turnover Intention in the Federal Government? The American Review of Public Administration 41: 168-84. [CrossRef]

Liu, Bangcheng, Jianxin Liu, and Jin Hu. 2010. Person-organization fit, job satisfaction, and turnover intention: An empirical study in the chinese public sector. Social Behavior and Personality: An International Journal 38: 615-25. [CrossRef] 
Locke, Edwin. 1970. Job satisfaction and job performance: A theoretical analysis. Organizational Behavior and Human Performance 5: 484-500. [CrossRef]

Locke, Edwin. 1991. The motivation sequence, the motivation hub, and the motivation core. Organizational Behavior and Human Decision Processes 50: 288-99. [CrossRef]

Locke, Edwin, and Gray Latham. 1990. Work motivation and satisfaction: Light at the end of the tunnel. Psychological Science 4: 240-46. [CrossRef]

Luna-Arocas, Roberto, and Joaquin Camps. 2008. A model of high performance work practices and turnover intentions. Personnel Review 37: 26-46. [CrossRef]

Maertz, Carl, and Rodger Griffeth. 2004. Eight Motivational Forces and Voluntary Turnover: A Theoretical Synthesis with Implications for Research. Journal of Management 30: 667-83. [CrossRef]

Maidani, Ebrahim. 1991. Comparative study of Herzberg's two-factor theory of job satisfaction among public and private. Public Personnel Management 20: 441. [CrossRef]

Markovits, Yannis, Ann Davis, Doris Fay, and Rolf van Dick. 2010. The link between job satisfaction and organizational commitment: Differences between public and private sector employees. International Public Management Journal 13: 177-96. [CrossRef]

Meier, Kenneth, and Alisa Hicklin. 2008. Employee Turnover and Organizational Performance: Testing a Hypothesis from Classical Public Administration. Journal of Public Administration Research and Theory 18: 573-90. [CrossRef]

Mihajlov, Snezana, and Nenad Mihajlov. 2016. Comparing public and private employees' job satisfication and turnover intention. MEST Journal 4: 75-86. [CrossRef]

Mobley, William. 1977. Intermediate linkages in the relationship between job satisfaction and employee turnover. Journal of Applied Psychology 62: 237-40. [CrossRef]

Moynihan, Donald, and Noel Landuyt. 2008. Explaining Turnover Intention in State Government: Examining the Roles of Gender, Life Cycle, and Loyalty. Review of Public Personnel Administration 28: 120-43. [CrossRef]

Moynihan, Donald, and Sanjay Pandey. 2008. The Ties that Bind: Social Networks, Person-Organization Value Fit, and Turnover Intention. Journal of Public Administration Research and Theory 18: 205-27. [CrossRef]

Naff, Katherine, and John Crum. 1999. Working for America: Does public service motivation make a difference? Review of Public Personnel Administration 19: 5-16. [CrossRef]

Nyberg, Aanthony. 2010. Retaining your high performers: Moderators of the performance-job satisfaction-voluntary turnover relationship. Journal of Applied Psychology 95: 440-53. [CrossRef] [PubMed]

Park, Chunoh, Nicholas Lovrich, and Dennis Soden. 1988. Testing Herzberg's Motivation Theory in a Comparative Study of U.S. and Korean Public Employees. Review of Public Personnel Administration 8: 40-60. [CrossRef]

Pedersen, Mogens Jin. 2013. Public Service Motivation and Attraction to Public Versus Private Sector Employment: Academic Field of Study as Moderator? International Public Management Journal 16: 357-85. [CrossRef]

Perry, James. 1997. Antecedents of Public Service Motivation. Journal of Public Administration Research and Theory 7 : 181-97. [CrossRef]

Perry, James, and Annie Hondeghem. 2008. Building theory and empirical evidence about public service motivation. International Public Management Journal 11: 3-12. [CrossRef]

Perry, James, and Lois Recascino Wise. 1990. The motivational bases of public service. Public Administration Review 50: 367-73. [CrossRef]

Peterson, Shari. 2004. Toward a Theoretical Model of Employee Turnover: A Human Resource Development Perspective. Human Resource Development Review 3: 209-27. [CrossRef]

Pitts, David, Marvel John, and Sergio Fernandez. 2011. So Hard to Say Goodbye? Turnover Intention among U.S. Federal Employees. Public Administration Review 71: 751-60. [CrossRef]

Podsakoff, Nathan, Jeffery LePine, and Marcie LePine. 2007. Differential challenge stressor-hindrance stressor relationships with job attitudes, turnover intentions, turnover, and withdrawal behavior: A meta-analysis. Journal of Applied Psychology 92: 438-54. [CrossRef] [PubMed]

Porter, Lyman William, Richard M. Steers, Richard T. Mowday, and Paul V. Boulian. 1974. Organizational Commitment, Job-Satisfaction, and Turnover among Psychiatric Technicians. Journal of Applied Psychology 59: 603-9. [CrossRef]

Price, James. 1989. The impact of turnover on the organization. Work and Occupations 16: 461-73. [CrossRef] 
Prihandinisari, Carolina, Azizur Rahman, and John Hicks. 2016. What Motivate Individuals to Join Public Service? Examining Public Service Motivation in a Non-Western Cultural Context. In 5th Global Business and Finance Research Conference. Berwick: World Business Institute, pp. 1-13.

Rahman, Azizur, and Najmul Hasan. 2017. Modeling Effects of KM and HRM Processes to the Organizational Performance and Employee's Job Satisfaction. International Journal of Business and Management 12: 35-45. [CrossRef]

Rosenfeld, Michael, and Steve Zdep. 1971. Instrinsic-extrinsic aspects of work and their demographic correlates. Psychological Reports 28: 359-62. [CrossRef]

Rutherford, Brian, Yujie Wei, JungKun Park, and Won-Moo Hur. 2012. Increasing job performance and reducing turnover: An examination of female Chinese salespeople. Journal of Marketing Theory and Practice 20: 423-36. [CrossRef]

Ryan, Richard, and Edward Deci. 2000. Intrinsic and extrinsic motivations: Classic definitions and new directions. Contemporary Educational Psychology 25: 54-67. [CrossRef]

Sachau, Daniel. 2007. Resurrecting the motivation-hygiene theory: Herzberg and the positive psychology movement. Human Resource Development Review 6: 377-93. [CrossRef]

Schleicher, Deidra, John Watt, and Gary Greguras. 2004. Reexamining the job satisfaction-performance relationship: The complexity of attitudes. Journal of Applied Psychology 89: 165-77. [CrossRef]

Sell, Lea, and Bryan Cleal. 2011. Job Satisfaction, Work Environment, and Rewards: Motivational Theory Revisited. LABOUR 25: 1-23. [CrossRef]

Smith, Deborah, and Joel Shields. 2013. Factors Related to Social Service Workers' Job Satisfaction: Revisiting Herzberg's Motivation to Work. Administration in Social Work 37: 189-98. [CrossRef]

Sousa-Poza, Alfonso, and Andres Sousa-Poza. 2007. The effect of job satisfaction on labor turnover by gender: An analysis for Switzerland. The Journal of Socio-Economics 36: 895-913. [CrossRef]

Spector, Paul, Tammy Allen, Steven Poelmans, Laurent Lapierre, Cary Cooper, Michael O’Driscoll, Juan Sanchez, Nureya Abarca, Matilda Alexandrova, Barbara Beham, and et al. 2007. Cross-national differences in relationships of work demands, job satisfaction, and turnover intentions with work-family conflict. Personnel Psychology 60: 805-35. [CrossRef]

Steel, Robert. 2002. Turnover theory at the empirical interface: Problems of fit and function. Academy of Management Review 27: 346-60. [CrossRef]

Steel, Robert, and John Lounsbury. 2009. Turnover process models: Review and synthesis of a conceptual literature. Human Resource Management Review 19: 271-82. [CrossRef]

Steers, Richard, Richard Mowday, and Debra Shapiro. 2004. The future of work motivation theory. Academy of Management Review 29: 379-87. [CrossRef]

Swailes, Stephen, and Saleh Al Fahdi. 2011. Voluntary turnover in the Omani public sector: An Islamic values perspective. International Journal of Public Administration 34: 682-92. [CrossRef]

Taylor, Jeannette. 2007. The impact of public service motives on work outcomes in Australia: A comparative multi-dimensional analysis. Public Administration 85: 931-59. [CrossRef]

Taylor, Jeannette. 2014. Public service motivation, relational job design, and job satisfaction in local government. Public Administration 92: 902-18. [CrossRef]

Taylor, Jeannette, and Ranald Taylor. 2011. Working hard for more money or working hard to make a difference? Efficiency wages, public service motivation, and effort. Review of Public Personnel Administration 31: 67-86. [CrossRef]

Taylor, Jeannette, and Janathan Westover. 2011. Job satisfaction in the public service. Public Management Review 13: 731-51. [CrossRef]

Tett, Robert, and John Meyer. 1993. Job satisfaction, organizational commitment, turnover intention, and turnover: Path analyses based on meta-analytic findings. Personnel Psychology 46: 259-93. [CrossRef]

Van Iddekinge, Chad, Philip Roth, Dan Putka, and Stephen Lanivich. 2011. Are you interested? A meta-analysis of relations between vocational interests and employee performance and turnover. Journal of Applied Psychology 96: 1167-94. [CrossRef] [PubMed]

Vandenabeele, Wouter. 2007. Toward a public administration theory of public service motivation. Public Management Review 9: 545-56. [CrossRef]

Vandenabeele, Wouter. 2008. Development of a public service motivation measurement scale: Corroborating and extending perry's measurement instrument. International Public Management Journal 11: 143-67. [CrossRef] 
Vandenabeele, Wouter. 2009. The mediating effect of job satisfaction and organizational commitment on self-reported performance: More robust evidence of the PSM-Performance relationship. International Review of Administrative Sciences 75: 11-34. [CrossRef]

Vandenabeele, Wouter. 2011. Who Wants to Deliver Public Service? Do Institutional Antecedents of Public Service Motivation Provide an Answer? Review of Public Personnel Administration 31: 87-107. [CrossRef]

Wang, Yau-De, Chyan Yang, and Kuei-Ying Wang. 2012. Comparing Public and Private Employees' Job Satisfaction and Turnover. Public Personnel Management 41: 557-73. [CrossRef]

Warr, Peter, John Cook, and Toby Wall. 1979. Scales for the measurement of some work attitudes and aspects of psychological well-being. Journal of Occupational Psychology 52: 129-48. [CrossRef]

Westover, Jonathan, and Jeannette Taylor. 2010. International differences in job satisfaction. International Journal of Productivity and Performance Management 59: 811-28. [CrossRef]

Wiersma, Uco Jillert. 1992. The effects of extrinsic rewards in intrinsic motivation: A meta-analysis. Journal of Occupational and Organizational Psychology 65: 101-14. [CrossRef]

Zimmerman, Ryan, and Todd Darnold. 2009. The impact of job performance on employee turnover intentions and the voluntary turnover process. A meta-analysis and path model. Personnel Review 38: 142-58. [CrossRef]

(C) 2020 by the authors. Licensee MDPI, Basel, Switzerland. This article is an open access article distributed under the terms and conditions of the Creative Commons Attribution (CC BY) license (http://creativecommons.org/licenses/by/4.0/). 